\title{
Indoor - soil gas radon relationship in the Central Bohemian Plutonic Complex
}

\author{
Ivan Barnet $\left({ }^{1}\right)$, Jitka Mikšová $\left({ }^{1}\right)$ and Ivana Fojtíková $\left({ }^{2}\right)$ \\ (') Czech Geological Survey, Prague 1, Czech Republic \\ $\left.{ }^{(}{ }^{2}\right)$ State Office for Nuclear Safety, Prague 1, Czech Republic
}

\begin{abstract}
The relationship of indoor radon measurements and radon in bedrock was studied in the granitoid Central Bohemian Plutonic Complex (CBPC). The indoor data were linked to vectorised geological and radon risk maps using the coordinates of particular dwellings. For each geological unit and rock type it was possible to calculate the statistical characteristics of indoor radon measurements. A clear relationship between indoor radon values and radon in bedrock was confirmed in all 7 districts situated on CBPC, where the study was performed.
\end{abstract}

Key words radon - indoor-bedrock relationship granitoids

\section{Introduction}

In the Czech Republic indoor radon measurements have been performed by the National Radiation Protection Institute (NRPI) since 1990. Up to now more than 130000 track-etch detectors (Kodak LR 115) have been distributed within the whole country. The primary random distribution of detectors based on the demands of district and regional authorities was soon changed for goal - directed distribution according to geological radon risk maps in various scales (Mikšová and Barnet, 2002).

The soil gas radon database has been built up since 1990. According to the uniform methodics used in the Czech Republic the soil gas radon data produced by the Czech Geological Survey and companies joined in the Association Radon Risk are comparable and reproducible and serve

Mailing address: Dr. Ivan Barnet, Czech Geological Survey, Prague 1, Klárov 3, 11821 Czech Republic; e-mail: barnet@cgu.cz as a basis both for radon risk mapping and statistical characterization of geological units and rock types. The content of the database is described in detail in Mikšová and Barnet (2002). Up to now the database comprises the soil gas radon data from more than 8900 test sites (15 measurement each). Since 1998 the Czech Geological Survey has vectorised all 214 map sheets of geological maps on a scale 1:50000. Regional radon data are also available in Austria (Friedmann, 2000), United Kingdom (Appleton and Miles, 2002), Germany (Siehl et al., 2000), Slovenia (Popit and Vaupotic, 2002), Luxembourg (Kies et al., 1996) and other countries.

The aim of the present study is to find a relationship between indoor and bedrock radon in the Central Bohemian Plutonic Complex (CBPC), Czech Republic.

\section{Experimental part}

\subsection{Geological setting}

The Central Bohemian Plutonic Complex (CBPC) forms the elongated body of $3200 \mathrm{~km}^{2}$ between Klatovy (SW) and Říčany near Prague (NE). According to the subdivision of the Variscan orogenetic belt in the Bohemian Massif 
(Matte et al., 1990) the CBPC is emplaced between two terranes - the weakly metamorphosed Barrandian on the NW (or Teplá-Barrandian unit) in the sense of other authors - e.g., Vrána and Štědrá (1997), Scheuvens (1999), Scheuvens and Zulauf (2000), Dörr et al. (2002), Zulauf et al. (2002) and medium to high grade metamorphosed Moldanubian assemblage of Precambrian and Proterozoic rocks on the SE. The tectonothermal history of both mentioned major units has differed since the Proterozoic (fig. 1).

The different P-T conditions are marked by the presence of largescale shear zones separating both units (West Bohemian shear Zone and Hoher Bogen shear zone on SW border and Central Bohemian shear zone on the SE border). The CBPC was emplaced along the Central Bohemian shear zone during late Devonian - early Carboniferous. The data from $\mathrm{Pb}-\mathrm{Pb}$ zircon evaporation ages, from $\mathrm{U}-\mathrm{Pb}$ zircon dating and ${ }^{40} \mathrm{Ar} /{ }^{39} \mathrm{Ar}$ biotite cooling ages presented by Janoušek et al. (2000a) cover the interval between 336 and 351 Myr.

The relatively long time of magmatic activity imprints the petrogenetic variety of granitoid types and as a consequence has led to newly used terminology - the plutonic complex. A long

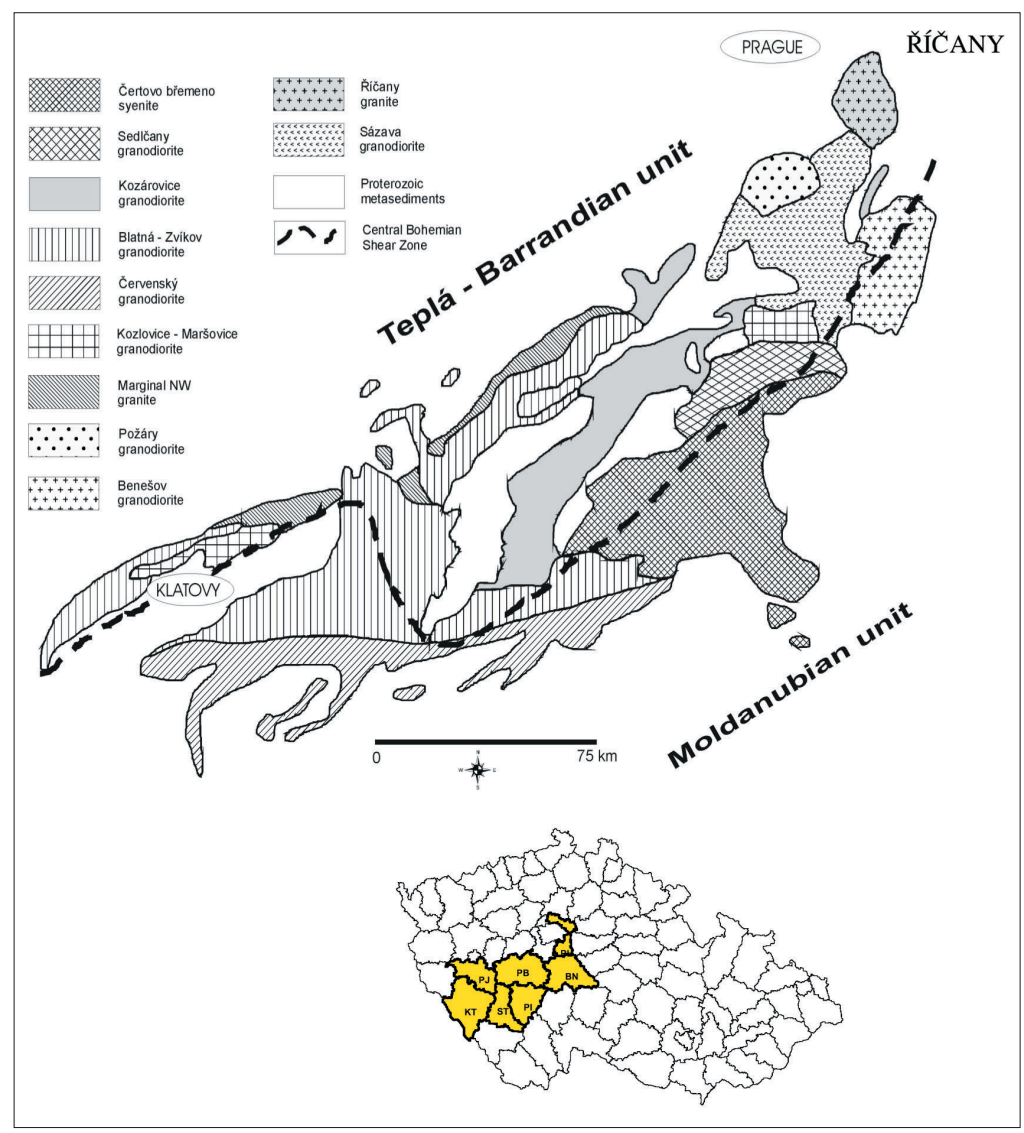

Fig. 1. The major granitoid types and the probable position of the Central Bohemian shear zone (modified after Chlupáč et al., 2002; Zulauf et al., 2002). Codes of districts: PH - Praha-East, BN - Benešov, PB - Příbram, PI - Písek, ST - Strakonice, PJ - Plzeň-South, KT - Klatovy. 
period of petrogenetic research of the CBPC resulted in distinguishing more than 20 granitoid types. On the contrary, data coming from petrogenetic, geochemical and geochronological similarities simplify the variety of granitoids into four suites (Janoušek et al., 2000a,b).

The northern part of CBPC is formed by Sázava suite comprising the amphibole - biotite diorite, granodiorite and tonalite. Ř́čany intrusion crops out in the northeastern part of CBPC and is characterized by presence of porphyritic K-rich biotite granite. The Čertovo břemeno on the south eastern border with Moldanubian unit is formed predominantly by porphyritic melagranite and melasyenite (durbachite). The major radiometric difference of Čertovo břemeno rocks from other granitoid types is caused by the relatively high concentration of uranium (15-20 ppm U are the frequent values) and presence of accessory minerals, namely zircon (up to $520 \mathrm{ppm}$ - reported by Holub, 1997). The geochemical and mineralogical composition of Certovo břemeno suite also causes the major indoor radon problems within all geological units on a countrywide scale. The Blatná suite comprised mostly of amphibole - biotite granodiorites forms the central and southwestern part of CBPC. The petrochemical differences of the four distinguished granitoid suites can be observed from AFM and $\mathrm{K}_{2} \mathrm{O} / \mathrm{SiO}_{2}$ graphs presented by Janoušek et al. (2000a).

A long time range of CBPC emplacement, the petrochemic and petrogenetic variety, and trends in tectonic and structural development implicate the importance of the Central Bohemian shear zone. The southwestern part of the shear zone was thoroughly studied (Pitra et al., 1999; Zulauf et al., 2002). The advantage of the southwestern part of the shear zone is the clearly observable tectonics separating CBPC from Moldanubian and relatively narrow extent of emplaced granitoids. On the other hand, the lateral extent of CBPC is about $40-50 \mathrm{~km}$ without distinct patterns or relics of shear zone orientation in the central part. The processes of multiple intrusive activities during the Variscan orogeny have covered the surface evidences of deep tectonics but regional geological studies (Matte et al., 1990) and seismic profiling help to recover the paleosituation (Tomek et al., 1997).
The indoor data from 7 former districts extend by their position the range of CBPC's granitoids. On the SE, S and SW of CBPC the bedrock is formed by medium to high grade metamorphosed Moldanubian paragneisses, migmatites and orthogneisses. The border with NW Tepla - Barrandian unit comprises the unmetamorphosed folded Palaeozoic sediments (Cambrian to Devonian shales, limestones and quartzites) and Lower Proterozoic slightly metamorphosed shales locally with silicites.

\subsection{Radon measurements}

After one year exposure time the indoor radon detectors (two for each dwelling) were processed in the National Radon Reference Laboratory in Kamenná near Př́ibram. The results of indoor geometric mean radon values for each dwelling were given in Equilibrium Equivalent Concentration (EEC). The Central Bohemian Plutonic Complex belongs to focused areas (Barnet et al., 2002) and the density of indoor measurements exceeds the general average in other areas. The indoor measurements (together 16 145) were selected from 7 former districts Praha-East (444), Benešov (2985), Př́íbram (6341), Písek (2164), Strakonice (1779), Plzeň-South (1596) and Klatovy (836) covering the areal extent of CBPC. For the purpose of this study the coordinates of family houses (digitized by the Czech Statistical Office) from 7 above mentioned districts were selected due to the direct contact of houses with bedrock.

The soil gas radon measurements were performed using the Scintrex RD 200 radonmeter. The soil gas radon was sampled using the losttip method from 15 probes and the third quartile of the data set was used as a classification parameter together with the permeability of the test site, given in three categories (low-medium-high). This method is fully described in Mikšová and Barnet (2002) and serves as a uniform method for building site assessment in the Czech Republic. The mean soil gas radon values for particular rock types were calculated from the radon database of the Czech Geological Survey. 


\section{Method of Geographical Information System (GIS) analysis}

The first phase of data processing was linking the database of centroids of dwellings (Czech Statistical Office) with the database of indoor radon measurements (National Radiation Protection Institute). This part of data processing was performed using the FoxPro 3.0 programme and identificators of particular dwellings and municipalities.

The resulting database from the area covering the territory of former 7 districts comprised 16145 dwellings with defined indoor radon mean and maximum value (EEC) and $x, y$ coordinates. In the second phase of data processing this database was put into GIS based on MGE 7.1, Oracle and Microstation 95 programmes and transformed into the ArcView 3.2. programme. The vectorised polygons of geological units and rock types were selected for the area covered by indoor measurements (16 map sheets of bedrock geological maps and radon risk maps on a scale $1: 50000$ ). The areal analysis performed using the MGE Analyst and Mapfinisher programmes linked the geological unit and rock type from the uniform legend for each dwelling.

As each geological map comprises about 40-90 different rock types according to petrography and mineralogic composition, these rock types were grouped with respect to prevailing radon risk calculated from the soil gas radon database for each rock type. Consequently each dwelling was characterised by indoor radon data (EEC) and corresponding mean soil gas radon concentration in the underlying rock type and category of radon risk from bedrock. The database of NRPI does not contain data on the technical characteristics of the dwellings (namely the quality of sealing) but a sufficient number of indoor radon measurements enables this load to be neglected.

\section{Results}

The mean and maximum indoor Rn concentrations in granitoid rock types of the CBPC are given in table I.
Table I. Mean and maximum indoor Rn concentrations in granitoids of CBPC (GR - granite, GD - granodiorite).

\begin{tabular}{lcc}
\hline \hline Type of granitoid & $\begin{array}{c}\text { Mean Rn } \\
\left(\mathrm{Bqm}^{-3}\right) \mathrm{EEC}\end{array}$ & $\begin{array}{c}\mathrm{Max} \mathrm{Rn} \\
\left(\mathrm{Bqm}^{-3}\right) \mathrm{EEC}\end{array}$ \\
\hline $\begin{array}{l}\text { GD Sedlčany } \\
\text { GR Čertovo }\end{array}$ & 488.2 & 572.4 \\
břemeno & 397.2 & 463.4 \\
GD Kozárovice & 350 & 400.8 \\
GD Benešov & 311.5 & 388.3 \\
GR Marginal NW & 310.2 & 377.4 \\
GD Blatná- & 270.5 & 340.8 \\
Zvíkov & & \\
GD Červenský & 219.8 & 285.6 \\
GR Ř́́čany & 167.9 & 211.4 \\
GD Kozlovice- & 157.9 & 191.7 \\
-Maršovice & & \\
GD Pošáry & 78.9 & 91.2 \\
\hline
\end{tabular}

Within each district the mean indoor radon concentration in dwellings situated on the particular rock type was plotted against mean soil gas radon concentration. Figure 2 illustrates the indoor - soil gas radon relationship in six districts. Mean indoor values are given in EEC.

For Praha - east district the dwellings were situated only on Quaternary sediments and granites (insufficient for graphical presentation). From fig. 2 it is obvious that increasing soil gas radon concentration in rock types generally also causes an increase in indoor radon values. In all studied districts the highest indoor and soil gas radon concentrations are observed in durbachites, granites and granodiorites. The other rock types with enhanced indoor and soil gas radon concentrations are Silurian black shales and Proterozoic metasilicites (both concentrating uranium).

The high indoor and soil gas radon concentration observed in Ordovician sediments of Strakonice district are bound to one village situated on the tectonic zone communicating with underlying granites.

Figure 3 illustrates the position of dwellings from 7 districts with indoor radon levels exceeding $1000 \mathrm{Bqm}^{-3}$ (EEC). Most of the houses are situated on the NW border of durbachites of Čer- 
Mean indoor - soil gas $\mathrm{Rn}$ in rock types Benešov district (2985 indoor Rn data)

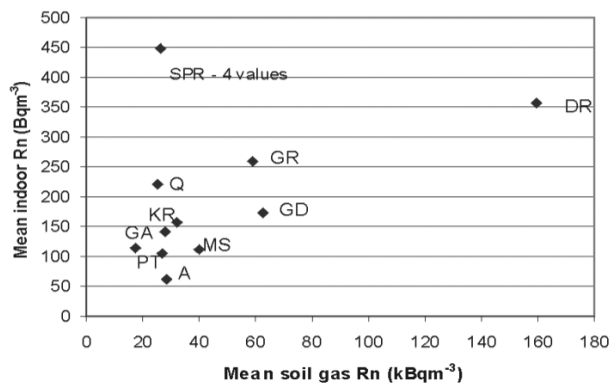

Mean indoor - soil gas $\mathbf{R n}$ in rock types Pisek district (2164 indoor Rn data)

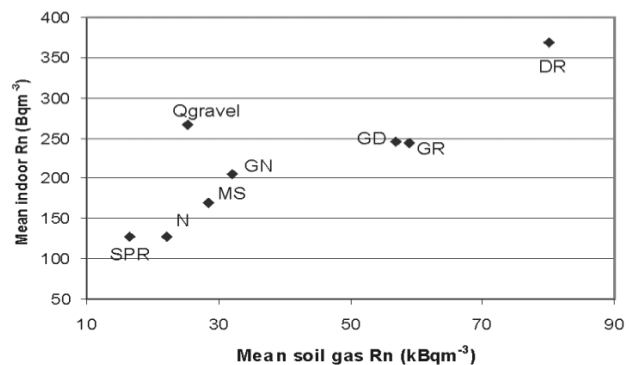

Mean indoor - soil gas $\mathrm{Rn}$ in rock types Plzeň south district (1596 indoor Rn data)

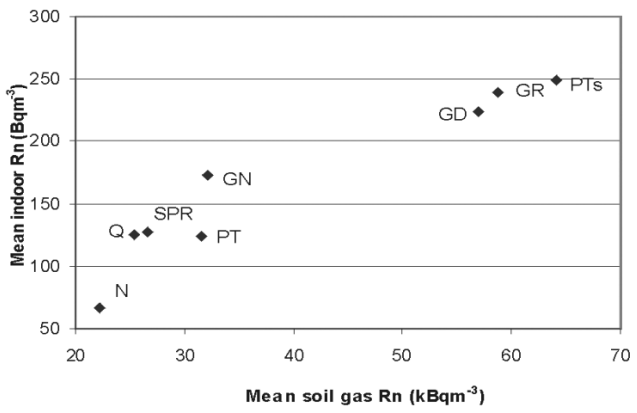

Mean indoor - soil gas $\mathrm{Rn}$ in rock types Príbram district (6341 indoor Rn data)

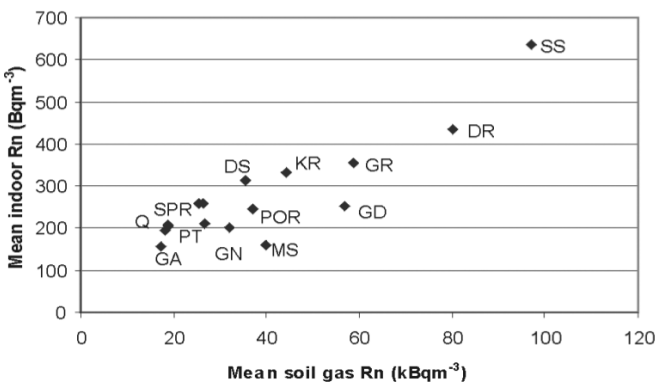

Mean indoor - soil gas $\mathrm{Rn}$ in rock types Strakonice district (1779 indoor Rn data)

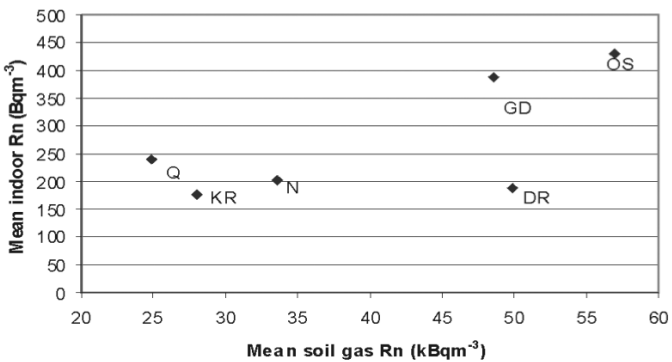

Mean indoor - soil gas $\mathrm{Rn}$ in rock types Klatovy district (836 indoor Rn data)

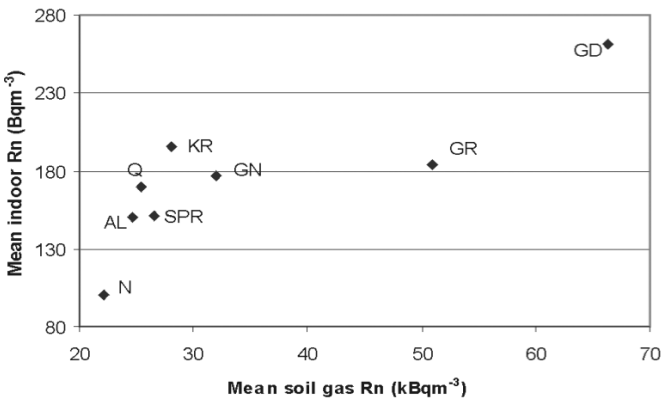

Fig. 2. The relationship of indoor and soil gas radon in the rock types of 6 Bohemian districts. Explanation of rock types: SS - Silurian Sediments, DR - Durbachites (syenites), GR - Granites, GD - Granodiorites, KR Moldanubian paragneisses, POR - Palaeozoic volcanites, MS - Quartzites, erlanes, GN - Moldanubian orthogneisses, DS - Devonian Sediments, PT - Proterozoic metasediments, SPR - Loess, A - Amphibolites, Q Quaternary, GA - gabbros, OS - Ordovician Sediments, KAS - Cambrian sediments, Qgravel - Quaternary gravel, $\mathrm{N}$ - Neogene sediments, AL - Alluvial sediments, PTs - Proterozoic silicites. 


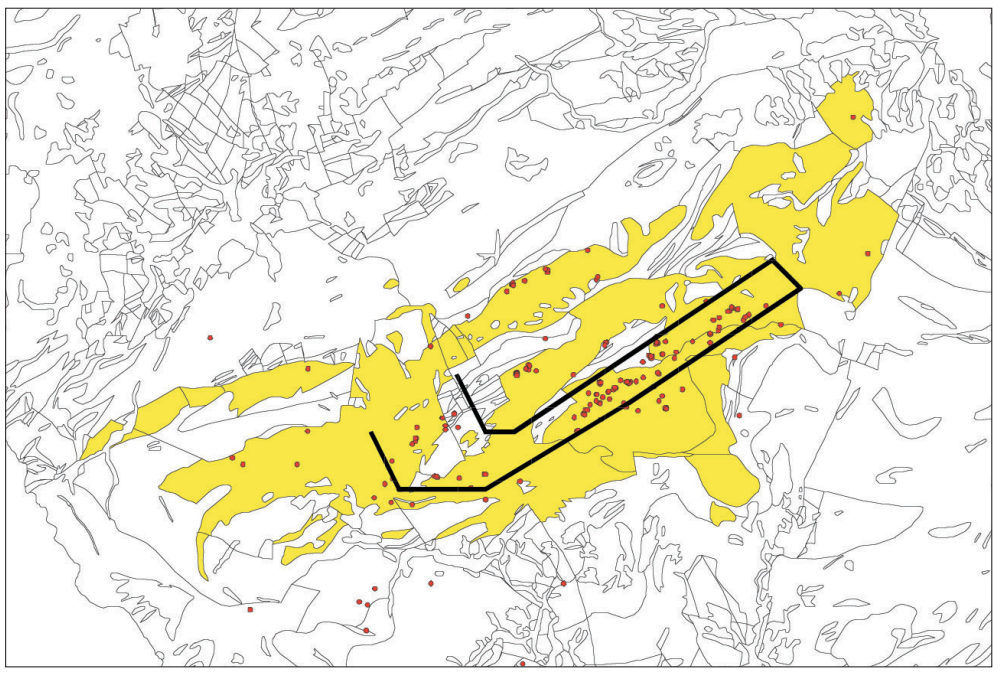

Fig. 3. The position of dwellings exceeding $1000 \mathrm{Bqm}^{-3}$ (EEC) within the CBPC. The reader should compare the framed segment with the course of Central Bohemian shear zone in fig. 1.

tovo břemeno and Sedlčany granodiorite but do not follow the contact of either rock body with other types of granitoids of CBPC. The position of high indoor radon dwellings resembles the orientation of the Central Bohemian shear zone, especially in the southeastern region of Čertovo břemeno syenite and Sedlčany granodiorite areas. This feature is not influenced by the density of indoor radon measurements and technical state of dwellings - in all 7 districts both factors are comparable. Therefore we suggest that the quasi-linear course of the high indoor radon dwellings position corresponds to the paleocontact of two major terranes - Teplá-Barrandian and Moldanubian.

\section{Conclusions}

A large-scale indoor $\mathrm{Rn}$ and bedrock $\mathrm{Rn}$ comparison was performed on the area of the Central Bohemian Plutonic Complex. The GIS analysis based on the coordinates of particular dwellings proved its efficiency in comparing the indoor radon data and corresponding detailed geology.
In all seven former districts the distinct trend of increasing indoor radon with increasing soil gas radon was proven in all rock types from Precambrian to Quaternary in spite of missing data on the technical state of dwellings. This fact supports the prognostic ability of radon risk maps based on the geology and soil gas radon measurements. Even if these maps are not used for deriving the radon risk on particular building sites (which is influenced by minor local geological features) they can serve as a useful tool for distributing the track-etch detectors on a wide country scale for setting the priorities of indoor $\mathrm{Rn}$ measurements.

The linear position of extremely high indoor $\mathrm{Rn}$ dwellings within the CBPC does not follow the local contacts of granitoid rocks or present tectonic network, but corresponds to the supposed course of the Central Bohemian shear zone. The palaeosuture dividing two Variscan terranes was effaced after emplacing the CBPC. The weakened zone of the upper crust in the border area between Teplá-Barrandian and Moldanubian terranes could prepare suitable a environment for radon migration along the deepseated shear palaeozones. The basement patterns 
of the buried Variscan fabric were copied into the shallow subsurficial levels. The evidence of the early development of the Bohemian part of the Variscan orogen can thus be related to the radon distribution on a regional scale.

\section{REFERENCES}

Appleton, D. and J. Miles (2002): Mapping radon-prone areas using integrated geological and grid square approaches, in Radon Investigations in the Czech Republic IX and the Sixth International Workshop on the Geological Aspects of Radon Risk Mapping, edited by I. BARnet, M. NEZnAL and J. MikšovÁ (CGS Praga), 34-43.

BARnet, I., J. Mikšová and I. FoJTíkovÁ (2002): The GIS analysis of indoor radon and soil gas radon in major rock types of the Czech Republic, in Radon Investigations in the Czech Republic IX and the Sixth International Workshop on the Geological Aspects of Radon Risk Mapping, edited by I. BARnet, M. Neznal and J. MikŠová (CGS Praga), 5-11.

Chlupáč, I., R. Brzobohatý, J. Kovanda and J. Stráník (2002): Geological History of the Czech Republic (Academia Prague), pp. 436 (in Czech).

DörR, W., G. Zulauf, J. Fiala, W. Franke and Z. Vejnar (2002): Neoproterozoic to Early Cambrian history of an active plate margin in the Teplá-Barrandian unit - a correlation of U-Pb isotopic dilution - TIMS ages (Bohemia, Czech Republic), Tectonophysics, 352, 65-85.

FriedmanN, H. (2000): Radon in Austria, in Radon investigations in the Czech Republic VIII and the Fifth International Workshop on the Geological Aspects of Radon Risk Mapping, Czech Geol. Surv., Prague, 79-85.

Holub, F.V. (1997): Ultrapotassic plutonic rocks of the durbachite series in the Bohemian Massif: petrology, geochemistry and petrogenetic interpretation, $\mathrm{Sb}$. Geol. Ved. (J. Geol. Sci.), Ložisková geologie, mineralogie, LG, 31, 5-25.

JANOUŠEK, V., D.R. Bowes, G. Rogers, C.M. Farrow and E. JELÍNEK (2000a): Modelling diverse processes in the petrogenesis of a composite batholith: the Central Bohemian Pluton, Central European hercynides, J. Petrol., 41 (4), 511-543.

JanoušEK, V., D.R. Bowes, C.J.R. Braithwaite and G. ROGERS (2000b): Microstructural and mineralogical evidence for limited involve ment of magma mixing in the petrogenesis of a Hercynian high $-\mathrm{K}$ calc-alkaline intrusion: the Kozárovice granodiorite, Central Bohemian Pluron, Czech Republic, Trans. R. Soc. Edinburgh, Earth Sci., 91, 15-26.

KIES, A., A. BIELL and L. Rowlinson (1996): Radon survey in the grand-duchy of Luxembourg - indoor measurements related to house features, soil, geology and environment, Environ Int., 22, 805-808.

Matte, PH., H. Maluski, P. Rajlich and W. Franke (1990): Terrane boundaries in the Bohemian Massif: result of large-scale Variscan shearing, Tectonophysics, 177, 151-170.

MiKŠOVÁ, J. and I. BARNET (2002): Geological support to the National Radon Programme (Czech Republic), Bull. Czech Geol. Surv., 77 (1), 13-22.

PITRA, P., J.P. BuRG and M. GUIRAUd (1999): Late Variscan strike-slip tectonics between the Teplá-Barrandian and Moldanubian terranes (Czech Bohemian Massif): petrostructurel evidence, J. Geol. Soc., 156, 1003-1020.

POPIT, A. and J. VAUPOTIC (2002): Indoor radon concentrations in relation to geology in Slovenia, Environ. Geol., 42, 330-337.

SCHEUVENS, D. (1999): Die tektonometamorphe und kinematische Entwicklung im Westteil der Zentralbohmischen Scherzone (Böhmische Masse) - Evidenz für variscischen Kollaps, Frankfurter Geowissenschaftliche Arbeiten, Ser. A, 18, p. 273.

Scheuvens, D. and G. Zulauf (2000): Exhumation, strain localization, and emplacement of granitoids along the western part of the Central Bohemian shear zone (Bohemian Massif), Int. J. Earth Sci., 89 (3), 617-630.

Siehl, A., R. Stegemann, R. Lehmann and M. Valdivia MANCHEGO (2000): Mapping of the geogenic radon potential in Germany - the state of matters, in Radon Investigations in the Czech Republic IX and the Sixth International Workshop on the Geological Aspects of Radon Risk Mapping, edited by I. BARNET, M. NEZNAL and J. Mikšová (CGS Praga), 92-99.

TomeK, C., V. Dvořaková and S. VRÁNA (1997): Geological interpretation of $9 \mathrm{~h}$ and $503 M$ seismic profiles in Western Bohemia, in Geological model of Western Bohemia related to the KTB borehole in Germany, edited by S. VRÁNA and V. ŠTĚdRÁ, J. Geol. Sci., Ser. Geology (Prague), 47, 43-50.

VRÁNA, S. and V. ŠTĚDRÁ (Editors) (1997): Geological model of Western Bohemia related to the KTB borehole in Germany, J. Geol. Sci., Ser. Geology (Prague), 47, pp. 240.

Zulauf, G., C. Bues, W. DörR and Z. Vejnar (2002): 10 $\mathrm{km}$ Minimum throw along the West Bohemian shear zone: evidence for dramatic crustal thickening and high topography in the Bohemian Massif (European Variscides), Int. J. Earth Sci., 91 (5), 850-864. 